\title{
Destabilization of the hard coal microstructure by a weak electric field
}

\author{
Oleksandr Molchanov ${ }^{1}$, Dmytro Rudakov ${ }^{2 *}$, Valerii Soboliev ${ }^{3}$, and Oleksii Kamchatnyi ${ }^{1}$ \\ ${ }^{1}$ Institute for Physics of Mining Processes National Academy of Science of Ukraine, 2a Simferopolska \\ St., 49005 Dnipro \\ ${ }^{2}$ National Mining University, Department of Hydrogeology and Engineering Geology, \\ 19 Yavornytskoho Ave., 49005 Dnipro, Ukraine \\ ${ }^{3}$ National Mining University, Department of Construction, Geotechnics, and Geomechanics, \\ 19 Yavornytskoho Ave., 49005 Dnipro, Ukraine
}

\begin{abstract}
This study aims to analyse physical and chemical changes in hard coal samples under the influence of low-intensity electric fields in comparison to the fragments of ejected coal, as well as the coal samples selected from the zones of high and low outburst hazard. We used physical methods including X-raying, electron paramagnetic resonance, thermogravimetric analysis, differential scanning calorimetry, laser diffraction analysis of particle sizes, IR-spectrometry, nuclear magnetic resonance, and Raman spectroscopy. It has been shown that destruction of coal organic matter (COM) can be caused not only by mechanical impacts or thermal influences but also weak electric fields. Scientific novelty consists in the fact that for the first time we established the identity of the COM destruction mechanism of mechanical-chemical activation and weak electric fields influencing on the previously destabilized coal microstructure. The destruction mechanism is based on thermal field regularities in both cases. The results obtained are of practical significance for the technologies of coal conversion to other products. The research results can be useful in the development of methods for reducing outburst hazard in coal mines.
\end{abstract}

\section{Introduction}

Physical and chemical properties of coal formed naturally under the simultaneous influence of electric and magnetic fields, temperature, pressure, and mechanical impacts on a coal seam in different geological conditions [ $1-3]$. Each of the aforementioned physical factors could play the leading role at different stages of coal formation with a certain probability in accordance with Le Chatelier-Brown's principle. The features of evolutional development of the coal seam including the degree of its coalification depend on changing these factors governing the thermodynamic and chemical equilibrium in the "coal - gas" system. The results of studying some physical properties of coal and the causes of appearance and retention of its unstable microstructure as an active state potentially capable of triggering

\footnotetext{
*Corresponding author: rudakovdv21@gmail.com
} 
and developing physical and chemical processes cannot be unambiguously interpreted within the framework of classical thermodynamics under the complex influence of multiple factors.

The system consisting of nano-sized particles [4] was previously studied mainly using the methodology of analysing micro-sized objects $[5,6]$ without proper attention to the mechanisms of carbon nano-phase appearance. Such nano-sized phases as carbon, hydrocarbon chains, graphene [7] etc. that acquire new properties in case of physicalchemical transformations [8] and, therefore, may have a critical influence on forming physical properties of coal [9], as a rule, were not taken into account.

Chemical reactions that occur in coal result, particularly, in phase and structural transformations and, generally, in destruction independently on physical parameters responsible for keeping the system equilibrium. In some cases, such reactions eventually generate a coal of high outburst hazard with the microstructure that store a big amount of internal energy potentially capable to initiate COM transition to a gas [10]. The restored history of forming new properties of coal is in a good agreement with the evolutional character of this process. This is very important conclusion for studying gas-dynamic phenomena in coal mines, which refer to the most important scientific problems still without a physically justified solution [11].

In this aspect, studying the influences of weak electric and magnetic fields on phase transitions in mechanically pre-activated coal is of growing scientific interest because natural tectonic activation manifests itself as the complex of mechanical effects accompanied by the amplification of electric and magnetic fields, increasing local temperatures, i. e. physical factors capable of initiating active chemical processes.

The majority of previous experiments did not evaluate the inflows of weak intensity fields because of their seemingly obvious low-energy effect. However, some recent experimental studies refuted the ideas about the insignificant contribution of weak electric field energy to the initiation of any physical and chemical process. For example, the efficiency of weak electric [12] and magnetic [13] field influences was demonstrated on the examples of transformation in coal, initiation of phase transitions and structural transformations in minerals of the carbonate group (siderite, calcite) [14], and the fractional composition of diamond particles synthesized in high-pressure chambers [15] etc.

The relevance of these studies is contingent on the need for creation of a unified physical concept about the nature of coal formation and transition of coal solid components to the gas without high-temperature activation of chemical reactions. In addition, the issues of formation of various carbon phases from free atomic carbon remain topical [16]. This may be of practical interest in production of new materials with specific physical, chemical, and technical properties.

The objective of this study is to conduct an analysis of physical-chemical changes in hard coal by comparing the samples taken from different seams and samples exposed to weak-intensity electric fields. This will allow demonstrating that COM destruction may be caused not only by mechanical impacts but also weak electric fields.

Analysing the experiments we took into account the results of T.M. Khrenkova and her colleagues in the field of coal mechanical chemistry [17]. The results of a comparative analysis of coal physical-chemical characteristics were used to justify the hypothesis of forming new coal properties under microstructural and phase instability [12].

\section{Materials and methods of research}

We used in experiments two sorts of hard coal that are gassy coal (I) (carbon content $86.6 \%$, hydrogen $5.7 \%$, vitrinite reflection index $R_{0} \geq 0.83 \%, Y=14 \mathrm{~mm}, V^{d a f}=36.2 \%$ ) and fat coal (II) (carbon content 88.2\%, hydrogen 3.9\%, vitrinite reflection index $R_{0} \geq 1.09 \%$, 
$Y=17 \mathrm{~mm}, V^{d a f}=31.3 \%$ ). The samples were taken from the seams both of high and low hazard of coal and gas outburst. The samples of the average mass $1.28 \mathrm{~g}$ were prepared from coal crushed to the fractions of $100 / 200 \mu \mathrm{m}$; according to laser diffraction analysis the size of intact coal particles ranged from 111.7 to $214.5 \mu \mathrm{m}$. Before conducting the tests, the samples were dried at a temperature of $308 \mathrm{~K}$ for 48 hours, with the maximum temperature of heating during electrical-physical treatments not exceeding $320 \mathrm{~K}$.

The experiments were conducted following the procedure described in [12]. The difference of the potential and the magnitude of the current were $1-300 \mathrm{~V}$ and $0.3 \mathrm{~A}$ respectively, each sample was processed about 4 hours. For X-ray phase analysis we used a DRON-3 unit. Numerous physical and chemical studies were carried out using the equipment for thermo-gravimetric analysis and differential scanning calorimetry TGA/DSC Mettler Toledo, the optical microscope LEICA DM ILM, the Shimadzu laser diffraction particle size analyser SALD-301V, and the calorimeter C-2000 IKA. Coal infrared spectra were recorded on a spectrometer ФCM-1201 with a transmission in the spectral range of $500-5500 \mathrm{~cm}^{-1}$. Nuclear magnetic resonance (NMR) studies were carried out following the method of the Institute for Physics of Mining Processes of the National Academy of Sciences of Ukraine (IPMP of NASU) [18, 19].

The NMR spectra of coal were recorded using a broad-line NMR spectrometer designed at the IPMP of NASU. The field strength of permanent magnet was $4600 \mathrm{E}$, the uniformity $210^{-6} \mathrm{E} / \mathrm{cm}$, the resonant frequency 19.6 MHz.

\section{Experiment results and discussion}

The NMR ${ }^{1} \mathrm{H}$ spectra (Table 1) showed a significant increase in the characteristic time of methane desorption (Table 2) [19]. Gas saturation of the coal samples treated with an electric field decreased by only a few per cents compared to intact coal. Simultaneously, the rate of methane emission increased for gassy coal (I) by three times and for fat coal (II) by 1.7 times [20]. The decrease in gas saturation of treated coal samples is due to the additional gas release by COM treated with an electric field.

Table 1. Characteristics of coal samples treated by an electric field.

\begin{tabular}{|l|c|c|c|c|c|c|c|c|c|}
\hline \multicolumn{1}{|c|}{ Material } & $I_{1}$ & $\Delta H_{1}$ & $I_{2}$ & $\Delta H_{2}$ & $S_{1}$ & $S_{2}$ & $S_{1} / S_{2}$ & $I_{2} / I_{1}$ & $\theta$ \\
\hline Gassy coal (I) treated & 1.53 & 6.617 & 0.725 & 0.370 & 0.822 & 12.658 & 0.065 & 0.474 & 2.14 \\
\hline Gassy coal (I) intact & 1.5877 & 6.347 & 0.731 & 0.472 & 1.054 & 12.635 & 0.083419 & 0.460618 & 2.27 \\
\hline Fat coal (II) treated & 1.597 & 6.363 & 0.425 & 0.391 & 0.507 & 12.694 & 0.03994 & 0.266124 & 0.86 \\
\hline Fat coal (II) intact & 1.532 & 6.11 & 0.318 & 0.668 & 0.641 & 11.377 & 0.056342 & 0.207572 & 1.09 \\
\hline
\end{tabular}

Table 2. Change of methane desorption time $T_{\text {des }}$ from the coal samples intact and treated by an electric field.

\begin{tabular}{|c|c|c|c|c|}
\hline \multirow{2}{*}{ Coal } & \multicolumn{2}{|c|}{ Gassy coal (I) } & \multicolumn{2}{c|}{ Fat coal (II) } \\
\cline { 2 - 5 } & Intact & Treated & Intact & Treated \\
\hline$T_{\text {des }}$, min & 25.9 & 79.5 & 39.1 & 68.0 \\
\hline
\end{tabular}

In Table 1 we used the nomenclature applicable to the ${ }^{1} \mathrm{H}$ NMR spectrum and namely: $I_{1}, I_{2}$ are the amplitudes of the wide and narrow spectral lines, respectively; $\Delta H_{1}, \Delta H_{2}$ are their widths; $S_{1}, S_{2}$ are their areas; $\theta$ is the humidity before measurements, $\%$.

The studies of gas-saturated samples losing the mass due to methane desorption were conducted at a temperature of $363 \mathrm{~K}$ using the gravimetric method. It has been shown that intact coal loses its mass at the rate higher than the samples treated with an electric field; 
the gas saturation of treated samples decreases. This is due to the additional gas release by COM that is undergone to destructive processes as a result of electric field influence.

Similar results of studying the coal samples taken from the seams of high outburst hazard, i.e. coal with a disturbed microstructure are given in [18]. An increase in the coal temperature from 293 to $323 \mathrm{~K}$ with simultaneous treatment by the electric field stimulated COM destruction significantly. The methane desorption rate evaluated using the methodology [20] was practically the same for all samples taken from low and high outburst hazard zones.

Coal sampled from the zones of low outburst hazard increased its chemical activity after grinding. According to the EPR results, the concentration of paramagnetic centres (PMC) increased from $(0.5-0.7) \cdot 10^{19} \mathrm{PMC} / \mathrm{g}$ to $(0.9-3) \cdot 10^{19} \mathrm{PMC} / \mathrm{g}$; additional treatment with an electric field increased the concentration to $(3.4-5) \cdot 10^{19} \mathrm{PMC} / \mathrm{g}$. EPR line expansion for coal from high outburst hazard zones [12] is caused by free radicals and can be described by Lorentz's equation. EPR line expansion occurs in cases of mechanical, thermal and electrical destruction of coal, i.e., due mainly to the thermal mechanism of chemical bond rupture. The stability of bonds can be influenced by the high content of impurities in coal composition.

After mechanical-electric processing coal samples acquired the electret potential difference $U_{P}$ evaluated by the compensation method. The electrochemical activity $A_{B}$ for ejected fat coal (II) (the mine named after O.F. Zasiadko, Ukraine) was $4.3 \cdot 10^{-5}$; in contrast $A_{B}=0.7 \cdot 10^{-2}$ for the non-hazardous zone.

The obtained correlation of changing the electret potential $U_{P}$ in time (Fig. 1) indicates an ultra-slow relaxation of the electret state triggered by a weak field. The results of studying the untreated and treated coal samples taken from the zones of low and high outburst hazard as well as ejected coal (Table 3) showed that the relaxation time of the electret state increases with the concentration of structural defects in the crystallites and the polymer matrix of coal and electric charges, which is in good agreement with the results presented in [21]. The energy stored in defects of the coal nanostructure increases accordingly.

Table 3. Characteristics of the electret state of coal treated with a weak electric field.

\begin{tabular}{|l|c|c|c|c|}
\hline \multicolumn{1}{|c|}{ Fat coal (II) } & $\begin{array}{c}\text { Initial electret } \\
\text { potential } U_{P}, \mathrm{mV}\end{array}$ & $\begin{array}{c}\text { Electrochemical } \\
\text { activity } A_{B}\end{array}$ & $n \cdot 10^{-18}, \mathrm{PMC} / \mathrm{g}$ & $\begin{array}{c}\text { Residual potential, } \\
U_{P, r e s}, \mathrm{mV}\end{array}$ \\
\hline $\begin{array}{l}\text { Low outburst hazard } \\
\text { zones }\end{array}$ & 2100 & $7 \cdot 10^{-3}$ & 60.0 & 0.88 \\
\hline $\begin{array}{l}\text { High outburst hazard } \\
\text { zones }\end{array}$ & 2750 & $9 \cdot 10^{-3}$ & 83.0 & 0.78 \\
\hline Ejected & 13 & $4.3 \cdot 10^{-5}$ & $6-14$ & 0.63 \\
\hline
\end{tabular}

The relaxation time of the electret state varies from $8 \cdot 10^{4}$ to $2 \cdot 10^{6} \mathrm{~s}$ for various samples, which exceeds the Maxwellian relaxation time ( $\sim 30 \mathrm{~s})$ several orders [22]. The concentration of defects increases as a result of mechanical grinding of coal and additional processing by an electric field. A comparative analysis of the electret state of coal from various zones and coal samples treated with an electric field reveals similar regularities of changing properties, especially for coal from the zones of high outburst hazard.

X-ray diffraction analysis allowed identifying two highly diffuse maxima on all diffractograms of studied coal samples, which corresponds to the angles $2 \theta$ of 24 and $43^{\circ}$ [12]. In the vicinity of the first maximum, there are the lines with the values of 0.338 , $0.371,0.403$ (weak line), 0.424 and $0.455 \mathrm{~nm}$. In the vicinity of the second maximum in the diffractograms of all initial samples we identified the lines that can be attributed to the crystalline phase with an inter-planar distance $d=0.198-0.200 \mathrm{~nm}$, which is close to the 
graphite line at $d=0.202 \mathrm{~nm}$ second by intensity.

Destructive processes in coal lead to an increase in the content of finer fractions, and correspondingly to an increase in the specific surface area. At the same time, the average particle size and content decrease by $3-8 \%$, the share of the finest fraction increases, and the share of the coarsest fraction decreases accordingly (Fig. 2).

Diffractograms point at the increase of "amorphousness" of the coal microstructure, which is confirmed by features of particle size distributions and the results of EPR studies that indicate the increase in the PMC concentration. Coal from the outburst zone is known to have a much larger sorption surface than coal from the same seam but not ejected. An increase in the internal specific surface area of coal may be an after-effect of shear deformations, chemical reactions, and the effect of weak electric fields.

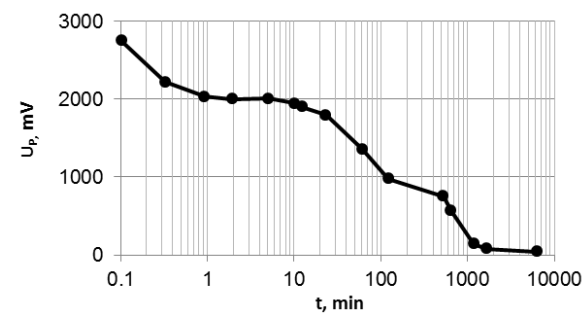

Fig. 1. Relaxation of the electret potential $U_{P}$ in time in a sample of fat coal (II) taken from the zone of high outburst hazard $\left(\Delta U_{P}=5 \%\right)$.

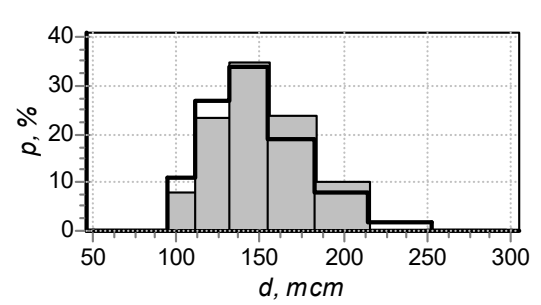

Fig. 2. Density of coal particle distribution $p$ over particle size $d$ : grey colour- untreated coal; bold line - coal treated with an electric field.

The IR-spectra of coal treated with an electric field are similar to the IR-spectra of coal taken from the seams of high outburst hazard. Destruction of bridge-type aliphatic chains correlates with a decrease in the optical density of bands $2860-2920 \mathrm{~cm}^{-1}$ (Fig. 3), which is in agreement with the valence and deformation vibrations of $\mathrm{C}-\mathrm{H}$ bonds. These bonds relate to the structures that contain $\mathrm{CH}_{2}$ and $\mathrm{CH}_{3}$ groups and may be caused by reducing the band of $3000-3100 \mathrm{~cm}^{-1}$ in aromatic hydrocarbons.

A detailed analysis of IR-spectroscopy of fat and gassy coal presented in [12, 13] also indicates the destructive nature of processes induced by the treatment using weak electric fields.

The coal samples selected from the zones of high outburst hazard contain an excess of $\mathrm{CH}_{3}$-groups with respect to the samples taken from low hazard zones. The studies [23, 24] established the correlation between the coal outburst hazard and the total content of $\mathrm{CH}_{2}$ and $\mathrm{CH}_{3}$ groups, as well as the ratio of carbon atoms with different hybridization of valent electrons $\left(\mathrm{sp}^{2} / \mathrm{sp}^{3}\right)$. The spectra of coal of high outburst hazard show an increase in the carbon content for the state of $\mathrm{sp}^{2}$-hybridization, which is possible with an increase of chain fragments containing $\mathrm{CH}$-groups. Using the NMR methods, cross-polarization, and Raman spectroscopy we have established the physical effects of increasing the content of $\mathrm{CH}_{3}$ groups in the zones of high outburst hazard and COM destruction that continues after the ejection. These effects are likely caused by the loss of stability of carbon and hydrocarbon chains with an increase in the electret potential and its further relaxation.

Numerical simulations showed that the influence of external electric charges leads to (1) bond breakage and (2) a random chain rupture after the decrease in the number of atoms in the chain to a certain critical value $[25,26]$. These results indirectly confirm the hypothesis of mechanical-electric stimulation of COM transition to the gas.

Intensive methane formation is preconditioned by the achievement of a critical level of $-\mathrm{CH}_{3}$ groups and a ratio of hydrogen atoms in the composition of the $=\mathrm{CH}$ and $-\mathrm{CH}_{3}$ groups of 4:1. As suggested by Ye. Ulianova this maintains an active process in the outburst zone. 


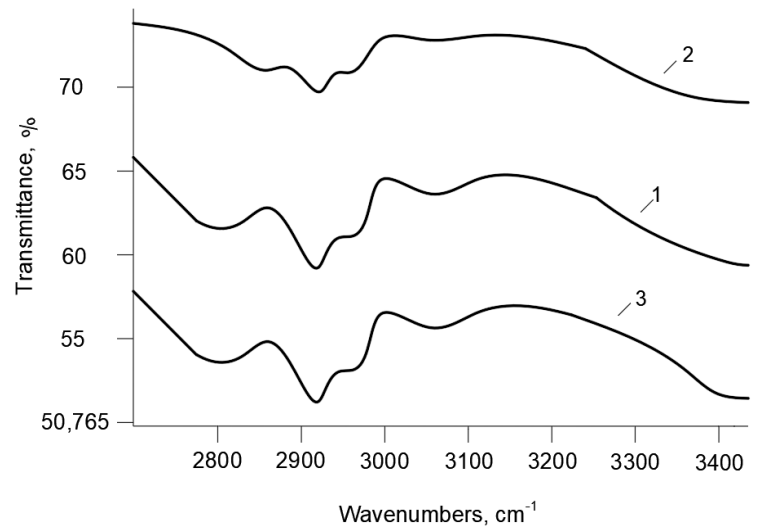

Fig. 3. A fragment of the IR spectrum of aliphatic saturated $\mathrm{C}_{\mathrm{al}}-\mathrm{H}$ groups: 1 - intact coal, 2 - coal treated with an electric field, 3 - coal treated with a magnetic field.

The additional bands with a frequency shift of $1190 \mathrm{~cm}^{-1}$ and $1430 \mathrm{~cm}^{-1}$ appear in the Raman spectra of coal samples from the zones of high outburst hazard (Fig. 4a) in comparison to the samples from low hazard zones in the D-band range. The band of the Raman spectrum of coal from high outburst hazard zones in the frequency shift range $1160-1190 \mathrm{~cm}^{-1}$ is associated with the vibrations of $\mathrm{C}-\mathrm{C}$ bonds in $=\mathrm{C}-\mathrm{C}=$ groups. A band with a frequency shift of $1436 \mathrm{~cm}^{-1}$ is caused by the appearance of polyin chains with $\equiv \mathrm{C}-\mathrm{C} \equiv$ bonds $[24,27]$.

The Raman spectra of coal from the zones of high outburst hazard are decomposed into 6 components (Fig. 4a), the Raman spectra of coal from low outburst hazard zones in the coalification series up to the anthracite are maximally decomposed into 5 components, the Raman spectra of ejected coal contain two components only (Fig. 4b). Similar regularities are observed for thermally treated coal, which may be the evidence of the same mechanism of physical-chemical transformations in coal.
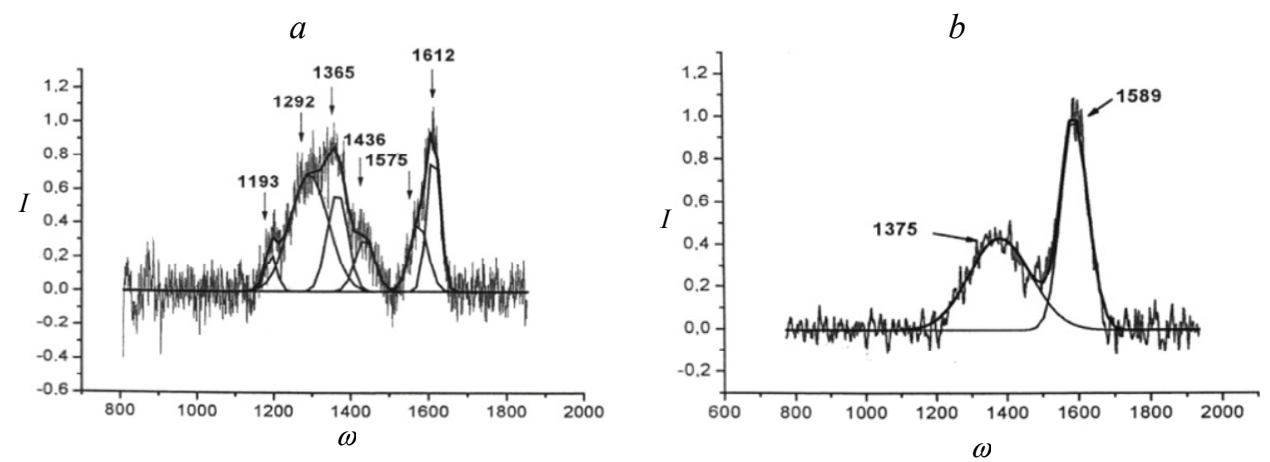

Fig. 4. Raman spectra of fat coal (II) taken from the seam $h_{6}^{\prime}$ of the mine named after O.O. Skochynskyi: $\mathrm{a}$ - in the zone of high outburst hazard; $\mathrm{b}$ - after the ejection. $I$ is the intensity of Raman scattering, dimensionless, $\omega$ is the frequency shift, $\mathrm{cm}^{-1}$.

The G-band maximum moves from the frequency shift of 1612 to $1589 \mathrm{~cm}^{-1}$, which is associated with the destruction of the chain fragments containing $\mathrm{CH}$-groups. The frequency shift of the G-band equals $1602 \mathrm{~cm}^{-1}$ for the Raman spectrum of a sample from a low outburst hazard zone. Changing features of the Raman spectra for coal from high outburst hazard zones and ejected coal confirms the conclusion made on the growth of the - 
$\mathrm{CH}_{3}$ group content in the zones of high outburst hazard and further $\mathrm{COM}$ destruction after the ejection due to reduction of the $=\mathrm{CH}-\mathrm{CH}=$ and $-\mathrm{CH}_{3}$ group contents.

Data generalization allows suggesting that methane forms during ejection mainly owing to the participation of hydrogen included in $=\mathrm{CH}$ groups $\left(\mathrm{sp}^{2}\right.$-hybridization $)$ and $-\mathrm{CH}_{3}$ groups ( $\mathrm{sp}^{3}$-hybridization).

\section{Conclusions}

As a result of studies of hard coal samples selected from the seams of high and low outburst hazard, and coal treated with a weak electric field, the following has been established.

Gas formation in coal treated with an electric field is a low-temperature process. Similar results can be achieved by heating coal to the temperatures exceeding $460 \mathrm{~K}$.

Gas generation in coal stimulated by an electrical field can be caused by the following reasons:

- breakage of the weakest chemical bonds in carbon and hydrocarbon chains;

- complete destruction of chains if they contain less than a critical minimum number of atoms critical to chain stability;

- hydrocarbon moleculization with unpaired electrons with subsequent formation of stable gas molecules;

- desorption of chemisorbed molecules as a result of excitation of their connections to internal surfaces by passing electric current;

- breakage of graphene bonds by forming an unstable chain that breaks down to form atomic carbon followed by forming the bonds with oxygen and hydrogen.

The high rate of chemical reactions can be due to the involvement of surface active centres as catalysts.

The obtained results show that destructive processes in COM can be initiated both by mechanical and electrical influences. Moreover, destabilization and destruction of chemical bonds under electrical influences may have even greatest effect on methane formation. Such a factor as an electric field may have a strong influence on generation of an additional amount of methane, for example, in underground coal gasification [28], and the formation of volatile coal.

Authors are grateful to Ye. Ulianova and her colleagues for assistance in carrying out the research and active discussion of the results obtained.

\section{References}

1. Khomenko, O., Sudakov, A., Malanchuk, Z., \& Malanchuk, Ye. (2017). Principles of rock pressure energy usage during underground mining of deposits. Naukovyi Visnyk Natsionalnoho Hirnychoho Universytetu, (2), 35-43.

2. Falshtynskyi, V.S., Dychkovskyi, R.O., Saik, P.B., Lozynskyi, V.H., \& Cabana, E.C. (2017). Formation of thermal fields by the energy-chemical complex of coal gasification. Naukovyi Visnyk Natsionalnoho Hirnychoho Universytetu, (5), 36-42.

3. Caceres, E., \& Alca, J.J. (2016). Rural Electrification Using Gasification Technology: Experiences and Perspectives. IEEE Latin America Transactions, 14(7), 3322-3328. https://doi:10.1109/TLA.2016.7587637

4. Ginzburg, A.I., \& Zhemchuzhnikov, Yu.A. (1960). Osnovy petrologii ugley. Moskva: Izdatel'stvo Akademii nauk SSSR.

5. Butuzova, L.F., Saranchuk, V.I., Gonchar, N.P., \& Shurpach, V.I. (1992). Vozmozhnosti IKspektroskopii pri issledovanii prirodnykh ugley i produktov ikh termodestruktsii. Fizikokhimicheskie svoystva uglya, 20-32. 
6. Obukhov, A.A., Frolkov, G.D., \& Artem'yev, V.B. (2000). Strukturno-khimicheskaya mekhanika ugley metamorficheskogo ryada plastov, opasnykh po vnezapnym vybrosam uglya $i$ gaza. Shakhty: YuRO AGN.

7. Ye, R., Xiang, Ch., Lin, J., Peng, Zh., Huang, K., Yan, Zh., Cook, N.P., Samuel, E.L.G., Hwang, Ch., Ruan, G., Ceriotti, G., Raji, A.-R.O., Marti, A.A., \& Tour, J.M. (2013). Coal as an abundant source of graphene quantum dots. Nature communications, 4(2943). https://doi.org/10.1038/ncomms3943

8. Jin, Ch., Lan, H., Peng, L., Suenaga, K., \& Iijima, S. (2009). Deriving carbon atomic chains from grapheme. Phys. Rev. Lett., 102, 205501. https://doi:10.1103/PhysRevLett.102.205501

9. Yanovskiy, Yu.G., Nikitina, Ye.A., Karnet, Yu.N., \& Nikitin, S.M. (2010). Modelirovanie deformatsii i razrusheniya grafena: razmernyy effekt, vliyanie defektov i modifikatsii poverkhnosti. Fizicheskaya mezomekhanika, 5(13), 139-147.

10. Sobolev, V.V. (2003). K voprosu o prirode obrazovaniya vybrosoopasnykh ugley. Sbornik nauchnykh trudov Natsionalnogo gornogo universiteta, 1(17), 505-511.

11. Antoshchenko, N.I., Radchenko, A.G., Ashikhmin, V.D., \& Radchenko, A.A. (2015). Osobennosti proyavleniya vybrosoopasnosti ugley v ryadu metamorfizma. Zbirnyk naukovykh prats Donetskoho natsinalnoho tekhnichnoho universytetu, (1), 14-21.

12. Pivnyak, G.G., Sobolev, V.V., \& Filippov, A.O. (2012). Phase transformations in bituminous coals under the influence of weak electric and magnetic fields. Naukovyi Visnyk Natsionalnoho Hirnychoho Universytetu, (5), 43-49.

13. Soboliev, V., Bilan, N., \& Samovik, D. (2013). Magnetic stimulation of transformations in coal. Annual Scientific-Technical Collection - Mining of Mineral Deposits, 221-225. https://doi.org/10.1201/b16354-41

14. Sobolev, V.V., Bilan, N.V., \& Khalimendik, A.V. (2017). On formation of electrically conductive phases under electro-thermal activation of ferruginous carbonates. Naukovyi Visnyk Natsionalnoho Hirnychoho Universytetu, 4(160), 27-35.

15. Sobolev, V.V., \& Bondarenko, E.V. (1993). The change in granulometric composition of diamond crystals when treating synthesis products in electromagnetic field. Sverkhtverdye materialy, (4),57-58.

16. Sobolev, V.V. (2010). Synthesis of nanosized phases from an atomic carbon. Advanced Materials Research, 123-125; 791-794.

17. Khrenkova, T.M., \& Chubarova, M.A. (1973). Mekhanokhimiya ugley. Khimiya tverdogo topliva, (1), 62-65.

18. Ul'yanova, Ye.V. (2012). Strukturnye i kompozitsionnye perestroyki $v$ iskopayemykh uglyakh. Saarbrucken: Palmarium Academic Publishing.

19. Molchanov, A.N. (2011). Metodicheskie osobennosti issledovaniya protsessa desorbtsii metana iz iskopayemykh ugley. Geotekhnichna mekhanika, (94), 133-139.

20. Sobolev, V., Rudakov, D., Stefanovych, L., \& Jach, K. (2017). Fizicheskoe i matematicheskoe modelirovanie usloviy vybrosa uglya i gaza. Mining of Mineral Deposits, 11(3), 40-49 https://doi.org/10.15407/mining11.03.040

21. Panchenko, Ye.M. (2009). Elektretnnoe sostoyanie v oksidakh. Moskva: Fizmatlit.

22. Electrets. (1980). Ed. G.M. Sessler. Berlin; Heidelberg; New York: Springer-Verlag.

23. Alekseyev, A.D., Molchanov, A.N., Ul'yanova, Ye.V., Zimina, S.V., \& Pichka, T.V. (2012). Preobrazovanie lokal'noy struktury iskopayemykh ugley v rezul'tate vybrosa i pod deystviem vysokikh davleniy. Fizika i tekhnika vysokikh davleniy, 22(1), 122-129.

24. Alekseyev, A.D., Ul'yanova,Ye.V., Trachevskiy, V.V., Ivashchuk, L.I., \& Zimina, S.V. (2010). Primenenie metodov kombinatsionnogo rasseyaniya i yadernogo magnitnogo rezonansa dlya issledovaniya genezisa struktury uglerodnykh nanomaterialov prirodnogo proiskhozhdeniya. Fizika i tekhnika vysokikh davleniy, 20(3), 126-140.

25. Sobolev, V.V. (2010). Zakonomernosti izmeneniya energii khimicheskoy svyazi v pole tochechnogo zaryada. Dopovidi Natsionalnoi Akademii Nauk Ukrainy, (4), 88-95. 
26. Sobolev, V.V., Baskevich, A.S., Bilan, N.V., \& Filippov, A.O. (2011). Ustoychivost' nanostruktury kamennogo uglya pri vozdeystvii elektricheskogo toka. Naukovyi Visnyk Natsionalnoho Hirnychoho Universytetu, (6), 80-84.

27. Alekseyev, A.D., Ul'yanova, Ye.V., Trachevskiy, V.V., Ivashchuk, L.I., Zimina, S.V., Borshch, T.V., \& Shpak, A.P. (2010). Preobrazovanie struktury iskopayemykh ugley v geomasshtabnom tekhnogeneze. Fiziko-tekhnicheskie problemy gornogo proizvodstva, (13), 48-59.

28. Pivnyak, G., Dychkovskyi, R, Bobyliov, O., Cabana, C.E. \& Smoliński, A. (2018). Mathematical and Geomechanical Model in Physical and Chemical Processes of Underground Coal Gasification. Solid State Phenomena, (277), 1-16. https://doi.org/10.4028/www.scientific.net/SSP.277.1 